\title{
Radiation-Associated Synovial Sarcoma: Clinicopathologic and Molecular Analysis of Two Cases
}

\author{
Jean-François Egger, M.D., Jean-Michel Coindre, M.D., Jean Benhattar, Ph.D., Philippe Coucke, M.D., \\ Louis Guillou, M.D. \\ University Institute of Pathology (J-FE, JB, LG) and Department of Radiooncology, University Hospital \\ (PC), Lausanne, Switzerland; Bergonié Institute and University of Bordeaux II (J-MC), Bordeaux, France
}

\begin{abstract}
Development of a soft-tissue sarcoma is an infrequent but well-known long-term complication of radiotherapy. Malignant fibrous histiocytomas, extraskeletal osteosarcomas, fibrosarcomas, malignant peripheral nerve sheath tumors, and angiosarcomas are most frequently encountered. Radiationassociated synovial sarcomas are exceptional. We report the clinicopathologic, immunohistochemical, and molecular features of two radiationassociated synovial sarcomas. One tumor developed in a 42-year-old female 17 years after external irradiation was given for breast carcinoma; the other occurred in a 34-year-old female who was irradiated at the age of 7 years for a nonneoplastic condition of the left hand. Both lesions showed morphologic features of monophasic spindle cell synovial sarcoma, were immunoreactive for cytokeratins, epithelial membrane antigen, CD99, CD117 (c-kit), and bcl-2 and bore the $t(X ; 18)$ (SYT-SSX1) translocation. We conclude that synovial sarcoma has to be added to the list of radiation-associated soft-tissue sarcomas.
\end{abstract}

KEY WORDS: Cytogenetics, Molecular biology, Pathology, Radiation-associated sarcoma, Radiation therapy, RT-PCR, Synovial sarcoma, Translocation.

Mod Pathol 2002;15(9):998-1004

Accounting for 10 to $15 \%$ of soft tissue sarcomas, synovial sarcoma (SS) is a relatively rare neoplasm that occurs predominantly in adolescents or young adults and presents as a large, deep-seated, limbbased mass, often in close association with large joints (knees and hips; 1, 2). Occasionally, it develops in older patients and/or involves unusual sites such as the abdominal wall, the head and neck

Copyright (C) 2002 by The United States and Canadian Academy of Pathology, Inc

VOL. 15, NO. 9, P. 998, 2002 Printed in the U.S.A.

Date of acceptance: May 21, 2002.

Address reprint requests to: Louis Guillou, M.D., Institut Universitaire de Pathologie, rue du Bugnon 25, 1011 Lausanne, Switzerland; e-mail: louis.guillou@chuv.hospvd.ch; fax: 41-21-314-7207.

DOI: 10.1097/01.MP.0000026616.41545.FF region, or viscera $(1,2)$. SS bears the $t(X ; 18)$ (SYTSSX) reciprocal translocation that seems to be specific for this tumor type and can be routinely detected in paraffin-embedded tissue using the reverse transcriptase-polymerase chain reaction (RT-PCR; 3-6). Radiation-associated sarcomas are an infrequent but well-known long-term complication of radiotherapy (7-16). They occur in about $1 / 1000$ patients who have undergone radiation therapy (7-11). Radiation-associated sarcomas are defined as sarcomas arising in a previously irradiated field after a latency period of $\geq 2$ years (12). They usually show a more aggressive clinical course associated with shortened patient survival as compared with sporadic sarcomas $(9-12,14)$. Highgrade pleomorphic sarcomas including so-called malignant fibrous histiocytomas, extraskeletal osteosarcomās, and fibrosarcomas are the histological types most frequently encountered; extraskeletal chondrosarcomas, malignant schwannomas, leiomyosarcomas, and angiosarcomas are much rarer $(7,9-12,14-16)$. Postradiation SS is exceptional. To our knowledge, only two cases have been previously described $(17,18)$, of which one only was fully documented and bore the $t(X ; 18)$ (SYT-SSX) translocation (18). In the present study, we describe two additional cases of radiation-associated SS. They occurred in previous radiation fields after latent periods of 17 and 27 years and showed classical histologic, immunohistochemical, and molecular features of SS.

\section{CASE REPORTS}

\section{Case 1}

A 25-year-old white woman presented in 1981 with a painless $4.5-\mathrm{cm}$ mass located in the supraareolar region of the right breast. There were no palpable axillary lymph nodes. A right mastectomy with lympadenectomy was performed in June 1981, and a pathologic diagnosis of poorly differentiated (Grade 3) invasive ductal carcinoma of the breast 
with concomitant axillary lymph node metastases was rendered. Subsequently, she received a total dose of 50 Gy to her right breast area, a 21-Gy boost to the tumor area, 52 Gy to the supraclavicular and axillary lymph nodes, and 48 Gy to the parasternal node fields. This radiotherapy regimen was given over a 2-month period without any major side effects; the number of sessions was not known. Complete remission was obtained and the patient discharged. After a 17-year disease-free latency period, she complained of an infraclavicular mass that appeared in the previous irradiated region. The mass measured $5.5 \mathrm{~cm}$ in maximal diameter and was situated within minor pectoral muscle, deep to the clavipectoral fascia. It extended to the previously cleared right axilla. This mass was marginally excised. The patient did not received any radiotherapy or chemotherapy after surgery. Nineteen months later, the tumor recurred locally and was, at that time, widely excised. Three months later, there was no evidence of local recurrence or distant metastasis.

\section{Case 2}

A 34-year-old woman presented with a 2-cm painless mass situated between the second and third metacarpus of the left hand. The nodule gradually enlarged for 7 months before she sought medical attention. At the age of 7 years, she had been irradiated for a congenital hemihypertrophy of the left distal extremity and left-hand gigantism caused by an angiomatous malformation. Doses and fractions were not known. The mass of the left hand was surgically removed and proved to be, on microscopic examination, a 6-cm, Grade 3 monophasic SS. Surgical margins were positive for tumor. Because of the presence of a visible residual tumor on postoperative magnetic resonance images, a postoperative chemotherapy was given, consisting of six courses of a combination of dacarbazine, ifosfamide, and doxorubicin followed by an amputation of the third metacarpus and finger. Pathological examination confirmed the presence of residual SS. The patient refused hand amputation and thus was given a total dose of $50.4 \mathrm{~Gy}$ in 28 sessions to the left hand. Twelve months later, left pleural effusion developed. Chest radiograms and computed tomography films revealed pulmonary metastases, including a $2-\mathrm{cm}$ nodular mass in the lower lobe of the left lung. The patient currently is being treated with systemic chemotherapy for her metastatic disease.

\section{MATERIALS AND METHODS}

Tissue for light-microscopic examination was fixed in $4 \%$ phosphate-buffered formalin and em- bedded in paraffin. Four- $\mu$ m-thick sections were stained with hematoxylin and eosin. The mitotic count was performed using a $40 \times$ lens (high-power field: $0.174 \mathrm{~mm}^{2}$ ). Histologic typing and subtyping were performed on paraffin-embedded sections stained with hematoxylin and eosin, using the World Health Organization histological classification of soft tissue tumors (19). Additional sections were stained with the following monoclonal and polyclonal antibodies: cytokeratin (monoclonal, clone AE1/AE3, diluted 1/100; Novocastra Laboratories Inc., Dedham, MA), epithelial membrane antigen (monoclonal, clone E29, diluted 1/50; Dakopatts, Glostrup, Denmark), CD34 (monoclonal, clone Qbend 10, diluted 1/80, Immunotech, Marseille, France), smooth muscle actin (monoclonal, clone 1A4, diluted 1/500, Sigma Chemical Company, St. Louis, MO), desmin (monoclonal, clone D33, diluted 1/40, Dakopatts), S100 protein (polyclonal rabbit, prediluted/ChemMate, DAKO), CD99 (monoclonal, clone 013, diluted 1/20, Signet Laboratories Inc., Dedham, MA), bcl-2 (monoclonal, clone bcl-2/100/D5, diluted 1/50, Novocastra Laboratories, Ltd, Newcastle upon Tyne, UK), and CD117 (c-kit; polyclonal rabbit, diluted 1/50, DAKO). Immunostaining was performed according to the avidin biotin complex method of Hsu et al. (20) with overnight incubation for bcl-2 antibody. Tissue sections were submitted to microwave oven heating before staining. All steps were performed at room temperature, and diaminobenzidine was used as a chromogen. Appropriate positive and negative controls were employed throughout.

\section{RNA Extraction}

Approximately $50 \mathrm{mg}$ of tumor were removed from paraffin blocks by scraping with a sterile scalpel. The tissue samples were deparaffinized by incubation 5 minutes in $1 \mathrm{~mL}$ of xylene at $65^{\circ} \mathrm{C}$; this reaction was repeated to remove residual paraffin. After centrifugation, the tissue was washed with 1 $\mathrm{mL}$ of $100 \%$ ethanol, followed by $1 \mathrm{~mL}$ of $70 \%$ ethanol. After 5 minutes of vacuum drying, the pellet was suspended in $250 \mu \mathrm{L}$ of lysis buffer (20 $\mathrm{mmol} / \mathrm{L}$ of Tris-HCl, pH 7.5; $20 \mathrm{mmol} / \mathrm{L}$ of EDTA; $1 \%$ sodium dodecyl sulfate; and 350-500 $\mu$ g of proteinase $\mathrm{K})$. The lysis buffer was preincubated at $37^{\circ}$ $\mathrm{C}$ for 30 minutes before tissue addition. After 16 to 48 hours' incubation at $55^{\circ} \mathrm{C}, 750 \mu \mathrm{L}$ of Trizol-LS reagent (Gibco BRL, Gaithersburg, MD) was added to the sample, and total RNA was extracted according to the manufacturer's instructions. The RNA pellet was redissolved in $40 \mu \mathrm{L}$ of RNase-free water and stored at $-80^{\circ} \mathrm{C}$. The quantity of the isolated RNA was determined by absorbance at 260 and 280 $\mathrm{nm}$. 


\section{RT-PCR Analysis}

Approximately $5 \mu \mathrm{g}$ of the extracted RNA was reverse transcribed into complementary DNA (cDNA), at $42^{\circ} \mathrm{C}$ for 50 minutes, in a volume of 20 $\mu \mathrm{L}$ with the specific reverse primers (65 ng of SSX-B and $15 \mathrm{ng}$ of $\beta$-actin-B), $0.5 \mathrm{mmol} / \mathrm{L}$ of dNTP, 10 $\mathrm{mmol} / \mathrm{L}$ of dithiothreitol, $50 \mathrm{mmol} / \mathrm{L}$ of Tris- $\mathrm{HCl}$ (pH 8.3), $40 \mathrm{mmol} / \mathrm{L}$ of $\mathrm{KCl}, 5 \mathrm{mmol} / \mathrm{L}$ of $\mathrm{MgCl}_{2}, 10$ $\mathrm{U}$ of RNase inhibitor, and $10 \mathrm{U}$ of Expand Reverse Transcriptase (Roche Diagnostics, Germany). The reverse transcriptase was inactivated at $98^{\circ} \mathrm{C}$ for 5 minutes, and the solution was kept at $-20^{\circ} \mathrm{C}$ until use. The amplification reactions $(20 \mu \mathrm{L})$ were performed, in presence of $2 \mu \mathrm{L}$ of the cDNA reaction, with an initial incubation step at $95^{\circ} \mathrm{C}$ for 5 minutes. The amplification profile of the PCR consisted of 35 cycles of denaturation at $94^{\circ} \mathrm{C}$ for 30 seconds, annealing at $60^{\circ} \mathrm{C}$ for 45 seconds, and extension at $72^{\circ} \mathrm{C}$ for 75 seconds. For each sample, two PCR amplifications were performed in parallel. One contained only the primer set necessary for the amplification of the SYT-SSX fusion gene transcripts, whereas the other was spiked with a set of primers for the ubiquitously expressed $\beta$-actin gene transcripts. $\beta$-actin primers were used at a lower concentration than were SYT-SSX fusion gene transcript primers ( 1 pmol in $20-\mu \mathrm{L}$ PCR reaction, instead of 10 pmoles for SYT-SSX). PCR amplifications were performed with the following primers: SYT-A (5'-CAGCAGAGGCCTTATGGATATGA-3'), SSX-B (5'-TTTGTGGGCCAGATG), $\beta$-actin-A (5'AGGCCAACCGCGAGAAGATGA-3'), and $\beta$-actin-B (5'- GCCGTGGTGGTGAAGCTGTAG-3'). The reaction products were subjected to electrophoresis in $2 \%$ agarose gel and visualized by ethidium bromide staining. The size of PCR products was $97 \mathrm{bp}$ for the SYT-SSX (SYT-SSX1 or SYT-SSX2) fusion gene transcripts and $274 \mathrm{bp}$ for the $\beta$-actin messenger RNA. The RT-PCR procedure was performed at least twice for each sample. For each PCR procedure, a classic $\mathrm{t}(\mathrm{X} ; 18)$-positive biphasic SS was used as a positive control. Negative controls consisted of $t(X$; 18)-negative desmoid tumor, $5 \times 10^{5}(5 \mu \mathrm{L}) \mathrm{SW} 480$ colorectal cancer cells, as well as distilled water devoid of template cDNA.

\section{Subtyping of the SYT-SSX Fusion Transcripts}

Three microliters of each PCR product was enzymatically hydrolyzed at $65^{\circ} \mathrm{C}$ for 1 hour with 5 units of the restriction enzyme TaqI (Roche) in a final volume of $10 \mu \mathrm{L}$. The digestion patterns of the PCR products were analyzed on $2 \%$ agarose gels and visualized by ethidium bromide staining. The size of digested products were 65 and $32 \mathrm{bp}$ for the SYT-SSX1 fusion gene transcripts but remained at $97 \mathrm{bp}$ for SYT-SSX2.
Subtyping was determined in parallel by singlestrand conformation polymorphism analysis. Aliquots of $5 \mu \mathrm{L}$ of PCR products were mixed with $5 \mu \mathrm{L}$ of denaturing buffer $(0.1 \mathrm{~m} \mathrm{NaOH}$ and $2 \mathrm{~mm}$ EDTA), heated at $50^{\circ} \mathrm{C}$ for 10 minutes. After addition of 1 $\mu \mathrm{L}$ of formamide dye, the samples were immediately loaded onto a $40 \%$ MDE gel (FMC BioProducts, Rockland, ME) and electrophoresed in $0.5 \times$ TBE buffer at $20^{\circ} \mathrm{C}$ and $300 \mathrm{~V}(20 \mathrm{~V} / \mathrm{cm})$ for 5 hours. The gels were stained with a SYBR Gold gel stain (Molecular Probes, Eugene, OR) diluted 1:10,000 in $1 \times$ TBE buffer and visualized under ultraviolet light using a CCD camera.

\section{RESULTS}

The two tumors show similar morphological, immunohistochemical, and molecular features. On microscopic examination, both neoplasms showed features of monophasic SS. They corresponded to highly cellular proliferations of spindle to round cells with relatively uniform fibroblast-like nuclei, arranged in fascicles or whorls, set in a variably collagenized intercellular matrix (Figs. 1 and 2). Numerous interspersed mastocytes and areas of myxoid changes were also present. In addition, dystrophic calcifications were visible in Case 1 (Fig. 1), and minute foci of tumor necrosis, in Case 2. The mitotic activity ranged from 4 (Case 1, primary tumor) to 16 (Case 2) mitoses per 10 high-power fields. The tumor recurrence in Patient 1 was slightly more cellular (or less myxoid) and more mitotically active (14 mitoses per 10 high-power fields) as compared with the case of the primary.

Immunohistochemically, tumor cells in both neoplasms were positive, at least focally, for EMA (Fig. 3A), bcl-2, CD99, and CD117 (c-kit). Both lesions also contained scattered isolated cells and/or

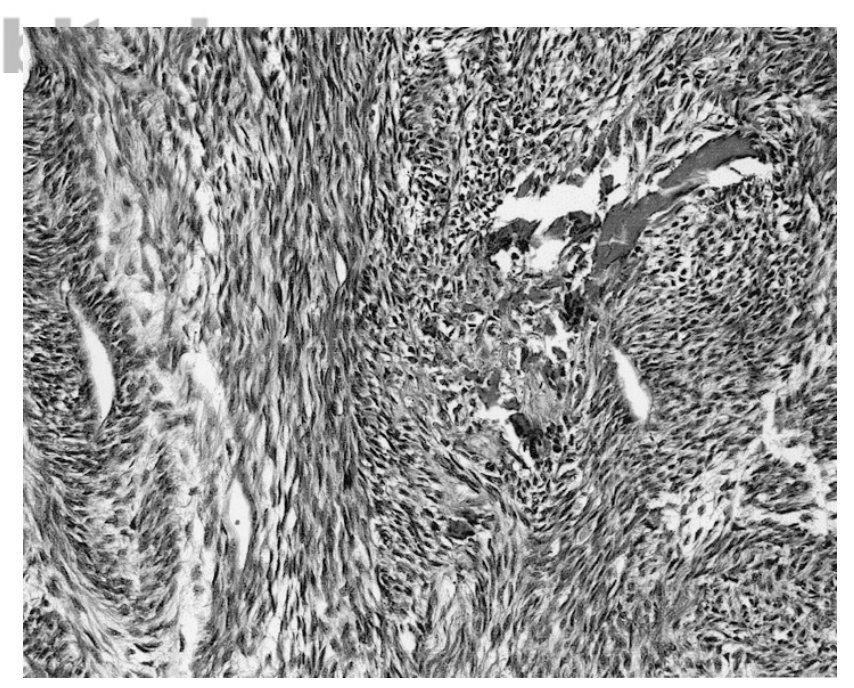

FIGURE 1. Case 1. Fascicular spindle cell proliferation with scattered minute dystrophic calcifications. Hematoxylin and eosin stain, $20 \times$. 


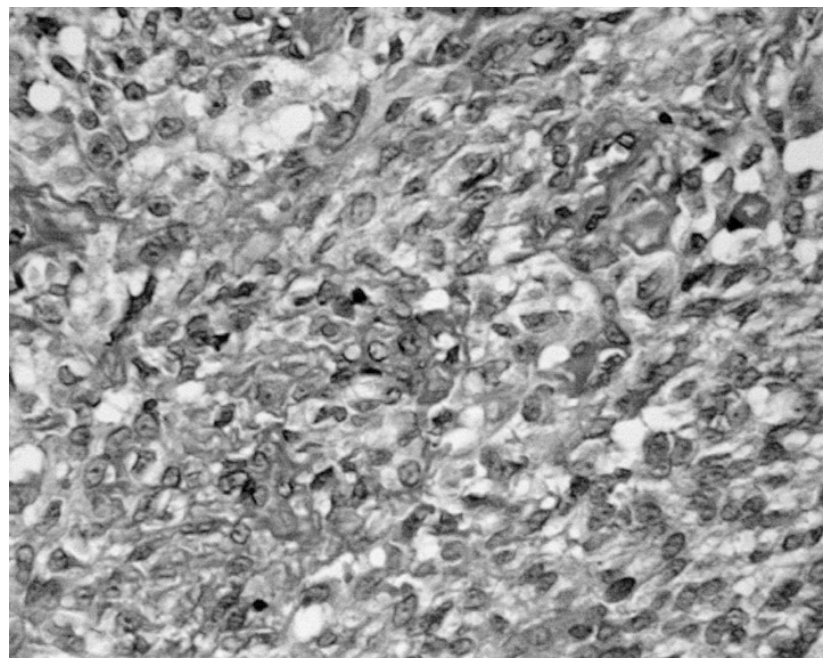

FIGURE 2. Case 2. Proliferation of round to spindle cells with opened chromatin nuclei and vague fascicular arrangement. Hematoxylin and eosin stain, $40 \times$

small tumor cell aggregates that were positive for cytokeratin (Fig. 3B), whereas stainings for S100 protein, HMB-45, desmin, and CD34 were negative. Few cells were also positive for smooth muscle actin in Case 2.

The two neoplasms bore the translocation $t(X ;$ 18) (SYT-SSX) (Fig. 4); the SSX1 gene was involved in both cases, including in the local recurrence of Patient 1 (data not shown).

\section{DISCUSSION}

SS is a relatively rare, deep-seated, often highly aggressive and metastasizing neoplasm that occurs frequently but not exclusively in adolescents and young adults. It involves primarily the limbs, especially lower limbs, where it is usually found in close

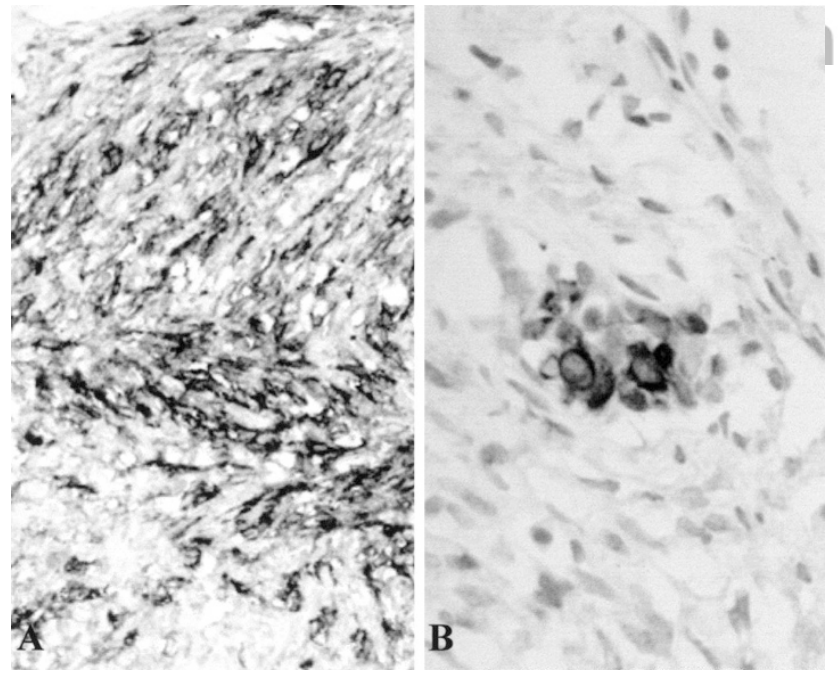

FIGURE 3. Case 2. Focal positivity of the spindle cells for epithelial membrane antigen (A) and cytokeratin (B).

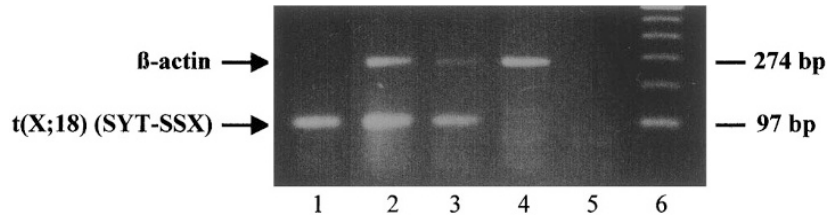

FIGURE 4. Detection of the $t(X ; 18)$ (SYT-SSX) translocation in two radiation-associated synovial sarcomas using RT-PCR. Lanes 1 and 2 correspond to Cases 1 and 2, respectively. For Lane 1, PCR amplifications contained only the primer set necessary for the amplification of SYT-SSX fusion gene transcripts, whereas in Lanes 2, 3, and 4 they were spiked with a set of primers for the ubiquitously expressed $\beta$-actin gene transcripts (positive control). A biphasic synovial sarcoma (Lane 3) was used as a positive control for the $\mathrm{t}(\mathrm{X}$; 18) detection. Negative controls consisted of $t(X ; 18)$-negative desmoid tumor (Lane 4) as well as distilled water devoid of template cDNA (Lane 5). Lane 6, pGEM DNA size markers (Promega, Madison, WI).

association with large joints, but it can also be observed in less common locations including abdominal wall, chest, mediastinum, bone, and viscera such as tonsil, pharynx, larynx, lungs, pleura, prostate, and so on $(1,2)$. This combination of rarity and unexpected situation is often a source of diagnostic difficulties for pathologists. The diagnostic issue is compounded by the fact that several histologic variants of SS have been described, including the biphasic, monophasic spindle-cell, poorly differentiated/round-cell, myxoid, calcifying, and bone-forming forms $(1,2)$. Immunohistochemistry and electron microscopy are very helpful ancillary techniques in this context. SS cells usually stain for epithelial membrane antigen, cytokeratins (few cells only), bcl-2, and CD99 but not for $\operatorname{CD} 34(1,2)$. Approximately $30 \%$ of SS are positive for S100 protein (21), and this has to be taken into consideration in the differential diagnosis with malignant schwannoma. Ultrastructurally, the spindle cells show inconstant features of epithelial differentiation (rudimentary intercellular junctions, external lamina; 1, 2).

The recent demonstration that SS bears a specific chromosomal translocation $\mathrm{t}(\mathrm{X}, 18)$ (SYT-SSX) has provided an additional tool for diagnosing equivocal cases and those displaying minimal or no immuno/ ultrastructural expression of epithelial differentiation (3-6). The translocation $t(X ; 18)$ that involves mainly the SSX1 or SSX2 genes, two closely related genes from chromosome Xp11, and the SYT gene from chromosome 18q11 result in the formation of a chimeric gene that encodes a transcription-activating protein. Using a consensus primer for SSX1 and SSX2, fusion gene transcripts may be detected in frozen tissue samples $(5,6,22)$ and in formalinfixed, paraffin-embedded material $(3,4,6)$, using the reverse transcriptase-polymerase chain reaction (RT-PCR), regardless of the treatment (chemotherapy or radiation therapy) given to the patient before molecular analysis (6) 
Ionizing radiation is currently recognized as a predisposing factor for cancer development in patients treated for both malignant and nonmalignant conditions. Among those radiation-related tumors, carcinomas, bone tumors, and leukemias are most frequently encountered (12). Criteria currently in use for defining postradiation neoplasms are as follows: (1) prior history of irradiation; (2) development of a secondary neoplasm in the field previously irradiated; (3) a latency period of $\geq 2$ years between radiation and the emergence of the second tumor; (4) proof that the secondary tumor is histologically different from the irradiated primary tumor $(11,12)$. Our two cases fulfilled those criteria and thus can be considered as radiation-associated SSs. Latency periods (17 and 27 y) are in keeping with the time interval of 2 to 64 years (mean: 10 to 17 y) reported for postradiation non-SSs (7, 9-12, 14-16). Along the same line, the amount of radiation received ( $\leq 71 \mathrm{~Gy}$ for one of our cases) is also in keeping with literature data $(7,9-12,15,16)$.

Malignant fibrous histiocytomas, extraskeletal osteosarcomas, fibrosarcomas, malignant peripheral nerve sheath tumors (malignant schwannomas), and angiosarcomas are the most frequently encountered postradiation sarcomas $(10-12,14-$ 16). Radiation-associated SSs seem to be exceedingly rare, with only two cases reported heretofore $(17,18)$, the clinicopathologic features of which are summarized in Table 1. Only one casê (18) that includes immunohistochemical data and shows the presence of the $t(X ; 18)$ SS translocation is adequately documented. The case reported by Mischler et al. (17) that is poorly illustrated and lacks immunohistochemical and molecular analysis remains questionable. On the single illustration provided, the morphology of the neoplasm is in keeping with a biphasic SS but could fit with a glandular malignant schwannoma, a carcinosarcoma, or a mesothelioma as well.

On the basis of three acceptable cases of postradiation SS (18; present cases), it appears that postradiation sarcomas do not differ clinically, morphologically, immunohistochemically, and molecularly from sporadic SS. All three cases were monophasic spindle to round-cell SS, and as expected, all variably express EMA, cytokeratins, bcl-2, and CD99 and were consistently negative for CD34. Reactivity for CD117 was focally observed in our two cases. As experience accumulates, it appears that some mesenchymal tumors other than gastrointestinal stromal tumors may express CD117 including angiosarcomas, Ewing's sarcoma/PNET $(23,24)$, and SSs (25). The SSX1 gene was involved in our two postradiation SS, contrasting with the SYT-SSX2 translocation observed in the case of van de Rijn et al. (18). In sporadic monophasic spindle- to round-cell SS,

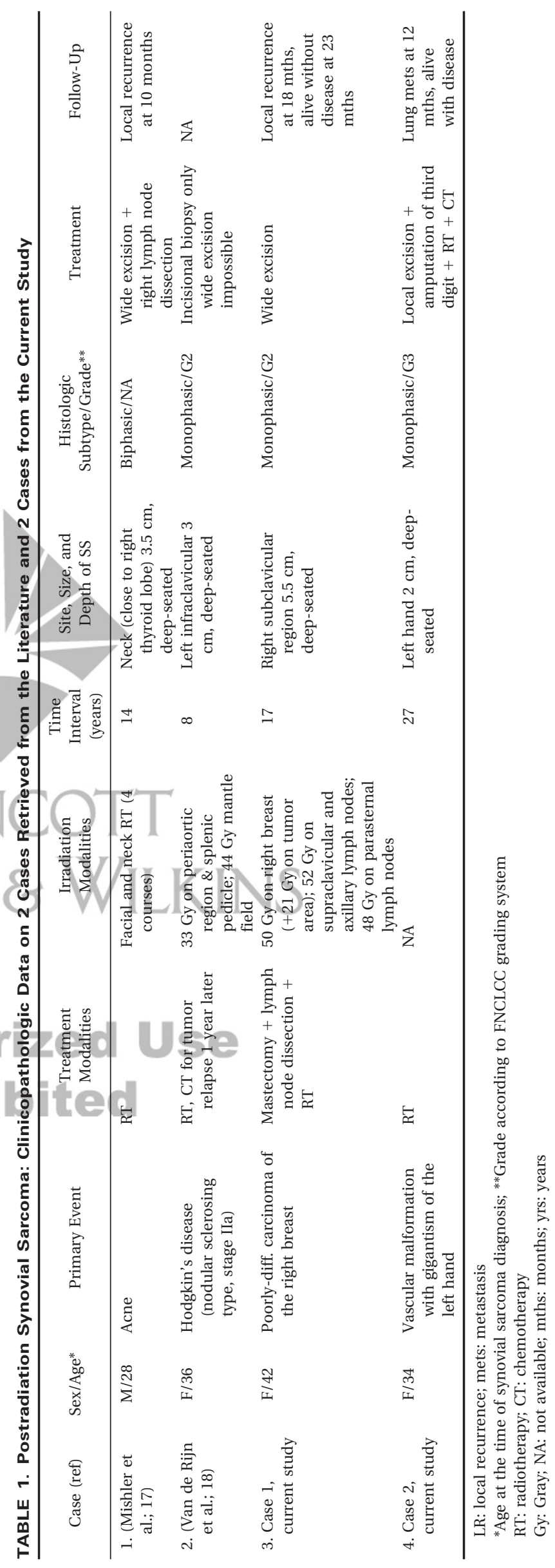


the $\mathrm{t}(\mathrm{X} ; 18)$ (SYT-SSX) translocation may involve either the SSX1 or the SSX2 genes $(6,22)$. We recently examined a series of 100 monophasic SS and found that the SSX1 gene was involved in $60 \%$ of the cases (unpublished data), a gene ratio that seems to be observed also in postradiation monophasic SS. Molecular studies on SS showed that the fusion gene type (SYT-SSX1 versus SYTSSX2) is concordant in primaries, recurrences, and metastases and is also constant over the course of the disease regardless of the treatment (radiotherapy and/or chemotherapy) given (6, 22). This also applies to postradiation SS because the same SYT-SSX1 translocation was observed in the primary tumor and the subsequent recurrence of one of our cases.

Differential diagnoses of radiation-associated SS mainly included recurring spindle-cell (sarcomatoid) carcinoma, monophasic spindle cell mesothelioma, fibrosarcoma, and malignant peripheral nerve sheath tumor (MPNST). Cellular schwannoma, malignant hemangiopericytoma, Ewing's sarcoma/PNET, melanoma, malignant extrapleural solitary fibrous tumor, and other spindle- to roundcell nonSSs should also be eliminated $(1,2)$. In a context of previously irradiated carcinoma, as in one of our cases, a postradiation spindle cell tumor is likely to be first diagnosed as a carcinomatous recurrence in the form of metaplastic or sarcomatoid carcinoma. Immunohistochemistry is not yêry helpful in making the distinction with SS because both tumor types may be positive, at least focally, for epithelial markers. Spindle cell carcinoma, however, is generally more pleomorphic and heterogeneous than SS and, more important, lacks the $\mathrm{t}(\mathrm{X}$; 18) translocation. There is a great morphological overlap between fibrosarcoma, MPNST, and SS, and many monophasic spindle cell SS were labeled as fibrosarcomas in the past. Thus, it is conceivable that some of those postradiation fibrosarcomas reported several years ago (11-13) might actually correspond to true monophasic spindle cell SS. Tumor cells in fibrosarcomas usually show a characteristic fascicular herringbone arrangement and are negative for keratins and EMA, as opposed to most SS. In MPNST, alternating hypercellular and myxoid areas are commonly observed in addition to a tendency for the tumor cells to form perivascular whorls and to infiltrate blood vessel walls, features which are less frequent in SS. Tumor cells in MPNST are also rarely positive for epithelial markers and almost never positive for cytokeratins 7 and 19, keratin subsets that are consistently found in SS (26). In addition, neither fibrosarcoma nor MPNST bear the $t(X ; 18)$ translocation, despite recent claims (27) that are likely to be ill founded (28).

As stressed by van de Rijn et al. (18), one may argue that the association between previous irradi- ation and SS occurrence is purely fortuitous. We recently reviewed the clinicopathologic features and outcome of $130 \mathrm{t}(\mathrm{X} ; 18)$-positive SS and found only two (1.5\%) cases (present cases) that had occurred in previous irradiation fields. Although we have no proof for that, it seems reasonable to think that ionizing radiation has played a significant role in the development of these secondary neoplasms, but other causes (unrecognized carcinogenes, genetic predisposition, and so on), taken in isolation or in combination might also have been oncogenic. Of interest was that none of our patients received chemotherapy in addition to radiation therapy for the original neoplasm.

In conclusion, this report shows that SS may develop in previous radiation treatment fields and, thus, should be added to the list of radiationassociated soft tissue sarcomas.

Acknowledgments: We thank the following pathologists and physicians for contributing case material and providing follow-up information when available: Drs. G. Zimmer and U. Grötzinger, Basel, Switzerland (Case 1) and Dr. J. Rivel, Pellegrin University Hospital, Bordeaux, and Dr. B. Bui, Bergonié Institute, Bordeaux, France (Case 2). We also thank Mrs. G. Gallagher and S. Burki for technical and photographic assistance, respectively.

\section{REFERENCES}

Fisher C. Synovial sarcoma. Ann Diagn Pathol 1998;2:401-21.

2. Weiss SW, Goldblum JR. Enzinger and Weiss's soft tissue tumors. 4th ed. St. Louis: Mosby; 2001. p. 1483-571.

3. Lasota J, Jasinski M, Debiec-Rychter M, Szadowska A, Limon J, Miettinen M. Detection of the SYT-SSX fusion transcripts in formaldehyde-fixed, paraffin-embedded tissue: a reverse transcription polymerase chain reaction amplification assay useful in the diagnosis of synovial sarcoma. Mod Pathol 1998;11:626-33.

4. Argani P, Zakowski MF, Klimstra DS, Rosai J, Ladanyi M. Detection of the SYT-SSX chimeric RNA of synovial sarcoma in paraffin-embedded tissue and its application in problematic cases. Mod Pathol 1998;11:65-71.

5. Van de Rijn M, Barr FG, Collins MH, Xiong QB, Fisher C. Absence of SYT-SSX fusion products in soft tissue tumors other than synovial sarcoma. Am J Clin Pathol 1999;112:43-9.

6. Guillou L, Coindre JM, Gallagher G, Terrier P, Gebhard S, de Saint Aubain Somerhausen N, et al. Detection of the synovial sarcoma translocation $\mathrm{t}(\mathrm{X} ; 18$ ) (SYT; SSX) in paraffin-embedded tissues using RT-PCR: a reliable and powerful diagnostic tool for pathologists. A molecular analysis of 221 mesenchymal tumors fixed in different fixatives. Hum Pathol 2001;32:105-12.

7. Mark RJ, Poen J, Tran LM. Postirradiation sarcomas: a single institution study and review of the literature. Cancer 1993; 73:2653-62.

8. Robinson E, Neugut AI, Wylie P. Clinical aspects of postirradiation sarcomas. J Natl Cancer Inst 1988;80:233-40.

9. Wiklund TA, Blomqvist CP, Raty J, Elomaa I, Rissanen P, Miettinen M. Postirradiation sarcoma. Analysis of a nationwide cancer registry material. Cancer 1991;68:524-31. 
10. Murray EM, Werner D, Greeff EA, Taylor DA. Postradiation sarcomas: 20 cases and a literature review. Int J Radiat Oncol Biol Phys 1999;45:951-61.

11. Amendola BE, Amendola MA, McClatchey $\mathrm{KD}$, Miller $\mathrm{CH}$. Radiation-associated sarcoma: a review of 23 patients with postradiation sarcoma over a 50 -year period. Am J Clin Oncol 1989;12:411-5.

12. Laskin WB, Silverman TA, Enzinger FM. Postradiation soft tissue sarcomas. An analysis of 53 cases. Cancer 1988;62: $2330-40$.

13. Kim JH, Chu FC, Woodard HQ, Melamed MR, Huvos A, Cantin J. Radiation-induced soft-tissue and bone sarcoma. Radiology 1978;129:501-8.

14. Lagrange JL, Ramaioli A, Chateau MC, Marchal C, Resbeut M, Richaud P, et al. Sarcoma after radiation therapy: retrospective multiinstitutional study of 80 histologically confirmed cases. Radiation therapist and pathologist groups of the Federation Nationale des Centres de Lutte Contre le Cancer. Radiology 2000;216:197-205.

15. Inoue YZ, Frassica FJ, Sim FH, Unni KK, Petersen IA, McLeod RA. Clinicopathologic features and treatment of postirradiation sarcoma of bone and soft tissue. J Surg Oncol 2000;75: 42-50.

16. Bloechle C, Peiper M, Schwarz R, Schroeder S, Zornig C. Postirradiation soft tissue sarcoma. Eur J Cancer 1995;31:31-4.

17. Mischler NE, Chuprevich T, Tormey DC, Ramirez G, Mack EA. Synovial sarcoma of the neck associated with previous head and neck radiation therapy. Arch Otolaryngol 1978;104:482-3.

18. van de Rijn M, Barr FG, Xiong QB, Salhany KE, Fraker DL, Fisher C. Radiation-associated synovial sarcoma. Hum Pathol 1997;28:1325-8.

19. Weiss SW. Histological typing of soft tissue tumours. In Sobin LH, editor. International histological classification of soft tissue tumours. 2nd ed. Berlin: Springer-Verlag, 1994.
20. Hsu SM, Raine L, Fanger H. Use of avidin-biotin-peroxidase complex (ABC) in immunoperoxidase techniques: a comparison between $\mathrm{ABC}$ and unlabelled antibody (PAP) procedures. J Histochem Cytochem 1981;29:577-80.

21. Guillou L, Wadden C, Kraus MD, Dei Tos AP, Fletcher CDM. S100 protein activity in synovial sarcoma. A potentially frequent diagnostic pitfall. Immunohistochemical analysis of 100 cases. Appl Immunohistochem 1996;4:167-75.

22. Kawai A, Woodruff J, Healey JH, Brennan MF, Antonescu CR, Ladanyi M. SYT-SSX gene fusion as a determinant of morphology and prognosis in synovial sarcoma. N Engl J Med 1998;338:153-60.

23. Miettinen M, Lasota J. Gastrointestinal stromal tumors. Definition, clinical, histological, immunohistochemical, and molecular genetic features and differential diagnosis. Virchows Arch 2001;438:1-12.

24. Ricotti E, Fagioli F, Garelli E, Linari C, Crescenzio N, Horenstein AL, et al. C-kit is expressed in soft tissue sarcoma of neuroectodermic origin and its ligand prevents apoptosis of neoplastic cells. Blood 1998;91:2397-405.

25. Tamborini E, Papini D, Mezzelani A, Riva C, Azzarelli A, Sozzi G, et al. C-kit and c-kit ligand (SCF) in synovial sarcoma (SS): an mRNA expression analysis in 23 cases. $\mathrm{Br} \mathrm{J}$ Cancer 2001;85:405-11.

26. Smith TA, Machen SK, Fisher C, Goldblum JR. Usefulness of cytokeratin subsets for distinguishing monophasic synovial sarcoma from malignant peripheral nerve sheath tumor. Am J Clin Pathol 1999;112:641-8.

27. O'Sullivan MJ, Kyriakos M, Zhu X, Wick MR, Swanson PE, Dehner LP, et al. Malignant peripheral nerve sheath tumors with $\mathrm{t}(\mathrm{X} ; 18)$. A pathologic and molecular genetic study. Mod Pathol 2000;13:1236-46.

28. Ladanyi M, Woodruff JM, Scheithauer BW, Bridge JA, Barr FG, Goldblum JR, et al. Letter to the editor. Mod Pathol 2001;14:733-5.
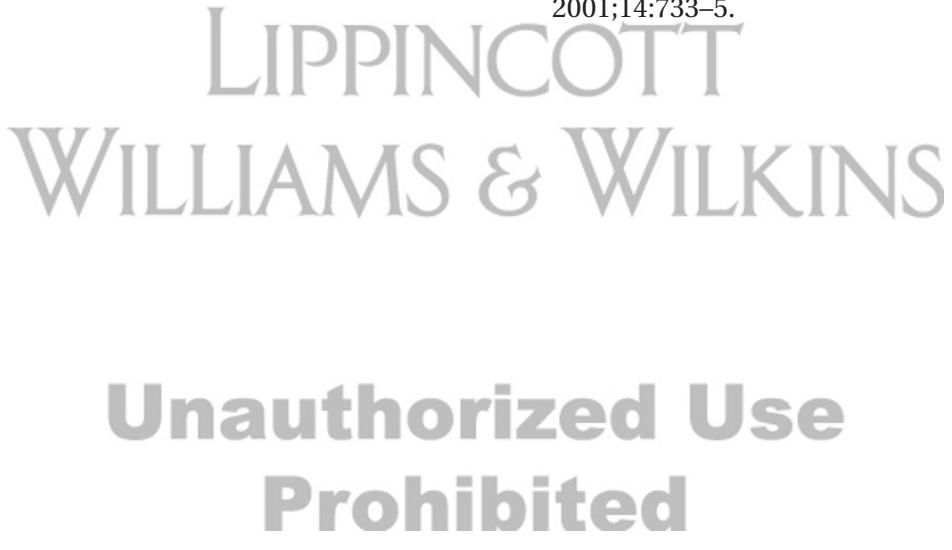